\title{
Comparative Studies of Students' Psychosocial Factors and Performance in Mathematics
}

\section{Omoniyi Israel Oginni}

Article History:

Received 06.10.2020

Received in revised form

15.06.2021

Accepted

Available online

01.10.2021

\begin{abstract}
The study investigated the influence of psychological factors (school environment, teachers' attribute, parental factors and students' disposition) on students' academic performance in Mathematics. The research design adopted for the study is the descriptive research of survey type and expo facto design. The sample for the study consisted of 150 participants randomly selected using stratified random sampling technique. The findings revealed that school environment has no significant influence on students performance in Mathematics. The study showed that the parental factors have significant influence on students performance in Mathematics. Also, students' disposition has significant influence on their performance in Mathematics. The result of this study therefore would be of great help to governments, teachers, students, professional policy makers and parents in providing a solid springboard to launch a new template to finding a lasting solution to the perennial low performance issues in Mathematics at the Senior Secondary Schools.
\end{abstract}

(C) IJERE. All rights reserved

Keywords: School environment; teachers' attribute; parental factors; students' disposition; performance; mathematics

\section{Introduction}

Education deals with inculcating moral values, positive thinking, attitude of helping, attitude of giving to society and ethical values that would bring changes in the society (Demirbağ,2020; Demirtaş \& Arslan,2018; Eyong, Ugada \& Aminu,2020; Hariyani, Ahmad \& Marsitin, 2021; Karagöz,2021). Education and Mathematics in every sense are fundamental in child development (Green, Little, Kamat, Oketch \& Vickers, 2007). This observation suggests that education and Mathematics are playing great role in the development of nations and they can be seen as central to their economic growth and social development. This role is explained in how education could helps individual to enhance life quality and a better standard of living. If the society do not get it right in the area of Mathematics, advancement in the area of science and technology will be an unrealistic dream. Mathematical knowledge indeed equips individuals with the skill to solve a wide range of practical tasks and scientific problems that they may encounter in life. Mathematics is learned because of many reasons. Bed (2017) stated that mastery of basic mathematical skills is needed in order to cope with the demand of life. Such demands include being numerically literate, gaining tools for future employment, developing the prerequisites for further education, and appreciating the relationship between Mathematics and technology. Secondly, Mathematics is the language of the sciences, and many disciplines depend on this subject as a symbolic means of communication. Thirdly, Mathematics education play an important part in developing students' general decision making and problem solving skills (Adewumi, et.al 2012). Several reasons for students abysmal performance in Mathematics has been highlighted, all the reasons are subsumed in psychosocial factor (Mtitu,2014). Firstly, the teacher factor, such as teaching styles and mastery of the subject matter, classroom management, communication skills, and personality. Secondly, the student factor like study habits, time management, attitude and interests towards Mathematics. Thirdly, the environmental factor such as parental values and attitudes, classroom settings and peer group. Teachers were responsible to the learning and experiences the students might engage everyday as well as setting of educational goals and total personality development (Limb \& Fullarton, 2001).

As a child move from infant to toddler and then to a preschooler, he learns how to speak, listen, write and read which later develop the child to achieve academically. The role of parents on children school achievement is well documented in numerous studies (Hill, 2001; Sidhu, 2005). Parental involvement and expectations over a child has a great impact on the academic achievement, and this may be as a result of environmental and economic factors. Some activities like helping children in reading, encouraging them to do their homework independently, monitoring their activities inside the house and outside the four walls of their house, and providing coaching services for improving their learning in Mathematics. Inability of a child to enjoy such activities work injury to Mathematics learning (Kolawole \& Oginni, 2009), and to a great extent impedes the ability of the students to understand and appreciate the subject even from the basis.(Robertson et.al. 2007). Children education does not depend on the teacher alone but also depend on their parents' awareness, interest and knowledge about handling and guiding their children at home. Uche and Chinyere (2013) studies have shown that parents with higher educational level could motivate the intellectual potentials within children that may lead to perform better in school.

omoniyi.oginni@eksu.edu.ng, orcid.org/0000-0002-1905-8881, Faculty of Education, Department of Science Education,Ekiti State University, 
The way of defining and measuring the socioeconomic status has changed significantly in the last years. According to Zhao, Valcke, Desoete and Verhaeghe (2011) several indicators such as home resources, personal library books, choice of school for children, study habits, self-concept, school environments, teachers' qualification and teaching strategies, government, parents' social class and parents' educational status, parents' inputs have been identified as factors responsible for students' poor academic performance in Mathematics (Ella, Akpabio \& Samson-Akpan, 2015).

There is documented evidence of influence of family size on students' academic performance in various subjects in school. The studies of Odok (2013) and Bilesanmi (2009) attested that small family sizes are linked to higher educational attainment. Large numbered families whether rich or poor are difficult to maintain, they are characterized with a high number of children, rowdiness and this does not create convenience for learning. They also create in the upbringing of children some identified problems such as feeding, poor clothing, insufficient funds, and lack of proper attention for children, disciplinary problems and malnutrition which impact negatively on children academic performance. Psychological factors that affect student's mind and thoughts include the following: anxiety, aspiration, encouragement, incentive, self- fulfilling prophecy, feedback, physical health, maturity, low self efficacy, Mathematics anxiety, lack of students' labor, prior knowledge of students, student attitude and commitment, peer pressure, locus of control, self efficacy among others. Positive attitude of teacher creates positive direction to students for learning Mathematics. Teachers should be able to teach students in such a way that students can practically do what they are taught, hearing it well by minimizing number of students in overcrowded classes and use of actual environment to make students understand Mathematics become imperative (Francis,2007; Maganga, 2013).Studies have shown that teacher experience is a major determinant in students' academic performance. Fettler (2009) posited that teachers who have spent more time studying and teaching are more effective overall and they develop higher order thinking skills for meeting the needs of diverse students and hence increasing their performance. Bilesanmi (2009) in her study found that teacher experience has the second most effective causal effect on students' achievement. Okoruwa (2009) found that teachers' teaching experience has significant effect on students' achievement in the sciences.

The physical environment of the school plays a vital role in the academic performance of the students. Bloom (2008) affirmed that environmental influences the acquisition of knowledge and skills. Adedipe (2007) concludes that the inadequacy of physical resources like conducive classroom, laboratories, libraries and other academic resources translate to poor results because it breeds underperformance in schools. Good acoustics environment are important in any learning situation, but noisy atmosphere often makes children struggle to hear and concentrate, defeating the learning process at the outset.

\section{Research Design and Method}

The research design adopted for the study is the descriptive research of survey type and expo factor design. The sample for this study consisted of one hundred and fifty (150) respondents which include teachers and students. 30 teachers, 120 students were randomly selected from six schools out of thirty six (36) senior secondary schools in Ekiti State. The instrument used for the study was a Questionnaire on Psychosocial Factors Associated with Students' Performance in Mathematics (QPASPM). QPASPM consisted of three sections, section A consist of items measuring the effect of parents' factor and influence of home environment on the teaching and learning of Mathematics; section B consist of items measuring the students' disposition towards teaching and learning of Mathematics; section C consist of items measuring the influence of teachers' attribute and the school environment on the performance of students in Mathematics. The academic performance of the students in Mathematics for the students that answered the questionnaire were collected through their teacher for the purpose of this study. Face and content validity of QPASPM was ensured and test re-test method was used to ascertained the reliability of the instrument. Kuder-richardson -20 was used to obtain 0.73 , which was high enough to adjudged the instrument reliable. Three research questions were raised and four hypotheses postulated. The data generated were analyzed using frequency count, percentage, mean, standard deviation, regression and Analysis of Variance (ANOVA) all at 0.05 level of significance.

Research Questions:- The following questions were raised to guide the study

1. What is the level of students' academic performance in Mathematics in secondary schools?

2. What is the relationship between the students' psychosocial factor and their performance in Mathematics? 
3. What is the interaction influence of the combined psychosocial factors on students

academic performance in Mathematics?

Research Hypotheses:- The following null hypotheses were postulated and tested at 0.05 level of significance

1 Teachers' attitude has no significant influence on students' performance in Mathematics.

2 School environment has no significant influence on students' performance in Mathematics

3 Parental factor has no significant influence on students' performance in Mathematics.

$4 \quad$ Students' disposition has no significant influence on students' performance in Mathematics.

In analyzing the questions, respondents' results in Mathematics were used. Frequency counts, percentages, mean and standard deviation score were used to analyze the result. The low level of students' academic performance in Mathematics starts from 0 to 49, the moderate level starts from 50 to 59 and the high level of students' academic performance in Mathematics is from 60 to 100 . The level of students' academic performance in Mathematics in secondary schools is presented in table 1

\section{RESULTS}

Research Question 1

What is the level of students' academic performance in Mathematics in secondary schools?

Table 1: Level of Students' academic performance in Mathematics in senior secondary schools

\begin{tabular}{lll}
$\begin{array}{l}\text { Level of students' academic performance in } \\
\text { Mathematics }\end{array}$ & No of Respondents & Percentage \\
Low (0-49) & 66 & 55.0 \\
Moderate (50-59) & 42 & 35.0 \\
High (60-100) & 12 & 10.0 \\
Total & $\mathbf{1 2 0}$ & $\mathbf{1 0 0}$ \\
\hline
\end{tabular}

Table 1 reveals the levels of students' academic performance in Mathematics in Senior Secondary Schools. The result showed that out of 120 respondents, 66 respondents representing 55.0 percent had low academic performance in Mathematics. Those whose academic performance in Mathematics is at moderate level were 42 respondents representing 35.0 percent while 12 respondents representing 10.0 percent had high academic performance in Mathematics. This showed that the level of students' academic performance in Mathematics in senior secondary schools was low. Figure 1 further revealed the level of students' academic performance in Mathematics.

Figure 1: Levels of students' academic performance in Mathematics in senior secondary schools.

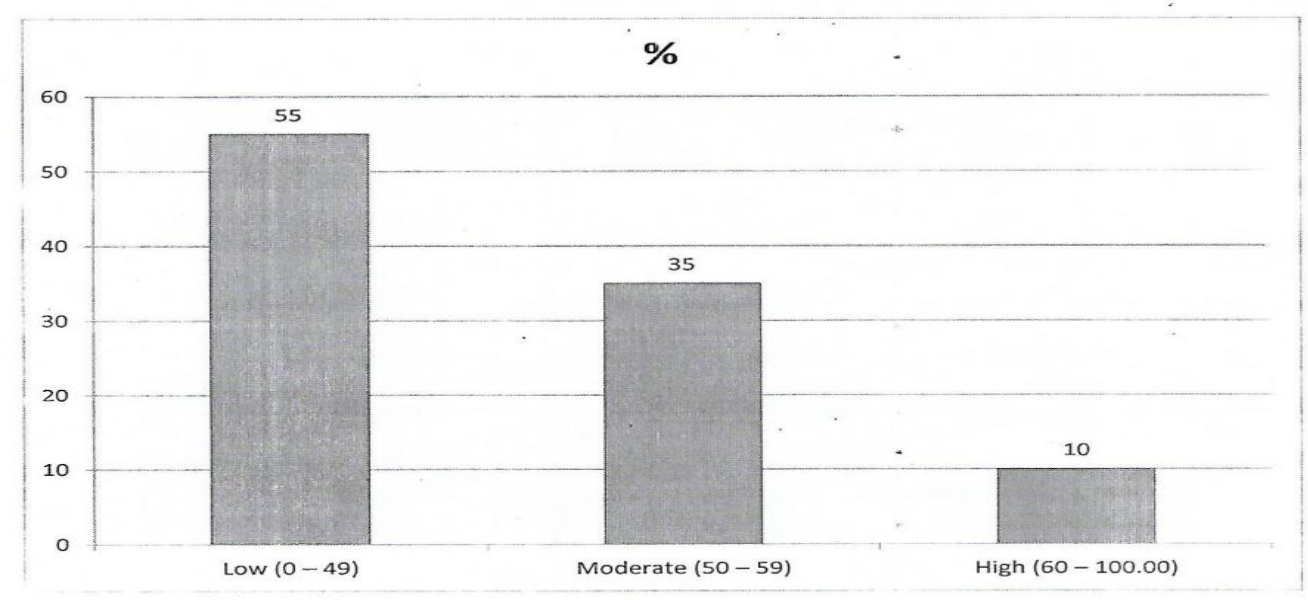

Research Question 2: What is the relationship between the psychosocial factor and student performance in Mathematics?

Table 2_; Regression analysis of psychosocial factors and students performance in Mathematics

\begin{tabular}{llcll}
\hline & & $\mathrm{R}$ & \\
Model & $\mathrm{R}$ & Square & Adjusted R Square & Std. Error of the Estimate \\
1 & $729^{\mathrm{a}}$ & 531 & .519 & 8.94766 \\
\hline
\end{tabular}


a. Predictors: (Constant), Students Disposition, Parental Factor, Teachers Attribute Environment

Table 2 indicates that there is a direct positive relationship between psychosocial factors and academic performance in Mathematics. $\mathrm{R}=0.729$, and the psychosocial factors contribute $53.1 \%$ of the students performance in Mathematics while the remaining factors are not captured in this study.

Table 3:- ANOVA analysis of psychosocial factors and students academic performance in Mathematics

\begin{tabular}{rcccccc}
\hline model & Sum of Squares & Mean Square & DF & Mean square & F. & Sig \\
1 & Regression & 3509.363 & 4 & 877.341 & 10.958 & $0.000^{*}$ \\
& Residual & 9206.962 & 115 & 80.061 & & \\
& Total & 12716.325 & 119 & & \\
\hline
\end{tabular}

Table 3 shows the four psychosocial factors in this study (students' disposition, parental factor, teacher's attribute and environmental factors) made significant contribution to the academic performance in Mathematics. $(\mathrm{F}=10.953, \mathrm{P}<0.05)$. The implication is that positive sense of psychosocial factors will enhance students performance in Mathematics.

Research Question 3: What is the interaction influence of the combined psychosocial factors on students academic performance in Mathematics?

Table 4:- Individual contribution of psychosocial factors on the students' academic performance in Mathematics

\begin{tabular}{|c|c|c|c|c|c|}
\hline \multirow[t]{3}{*}{ Model } & \multicolumn{5}{|c|}{ Standardized } \\
\hline & \multicolumn{2}{|c|}{ Unstandardized Coefficients } & Coefficients & & \\
\hline & B & Std. Error & BETA & $\mathrm{T}$ & Sig \\
\hline (Constant) & 16.161 & 1.513 & & 10.681 & .000 \\
\hline Teachers Attribute ( $\left.\mathrm{x}_{1}\right)$ & .553 & 104 & 444 & 5.317 & .000 \\
\hline Environment $\left(\mathrm{x}_{2}\right)$ & .344 & .088 & .178 & 3.909 & .000 \\
\hline Parental Factor $\left(x_{3}\right)$ & .416 & .169 & .304 & 2.462 & 013 \\
\hline $\begin{array}{l}\text { Students Disposition } \\
\left(\mathrm{x}_{4}\right)\end{array}$ & .588 & .090 & 477 & 6.533 & .000 \\
\hline
\end{tabular}

Table 4 shows the regression model is $\mathrm{y}=16.161+0.553 \mathrm{x}_{1}+0.344 \mathrm{x}_{2}+0.416 \mathrm{x}_{3}+0.588 \mathrm{x}_{4}$. This implies that ;For every unit increase in academic performance $(y)$, there is corresponding 0.553 increase in the teachers' attribute; For every unit increase in academic performance, there is corresponding 0.344 increase in the environmental factor; For every unit increase in academic performance, there is corresponding 0.416 increase in the parental factor; For every unit increase in academic performance, there is corresponding 0.588 increase in the students disposition. However, 16.161 unit increase accounted for other factors that contributed to academic performance outside the psychosocial factors considered in this study. This implies that the students' disposition is the best predictor of academic performance in Mathematics while the students environment is the least predictor of students academic performance in Mathematics.

\section{Testing of Hypotheses}

Hypothesis 1: Teachers' attitude has no significant influence on students' performance in Mathematics

Table 5: Two-way Analysis of Variance (ANOVA) for influence of teachers' attribute on students' academic performance in Mathematics

\begin{tabular}{|c|c|c|c|c|c|c|}
\hline Source & & Sum of Squares & Df & Mean Square & $\mathbf{F}$ & Sig. \\
\hline Corrected Model & & $7597.747^{\mathrm{a}}$ & 32 & 237.430 & 9.750 & $.000^{\prime}$ \\
\hline Intercept & & 148481.030 & 1 & 148481.030 & 6097.416 & $.000^{\circ}$ \\
\hline Teachers' Attribute & & 114.925 & 11 & 10.448 & .429 & .939 \\
\hline Performance & & 4695.835 & 2 & 2347.917 & 96.418 & $.000^{\circ}$ \\
\hline $\begin{array}{ll}\text { Teachers' } & \text { Attitude } \\
\text { Performance } & \end{array}$ & * & 2125.416 & 19 & 111.864 & 4.594 & $.000^{\circ}$ \\
\hline Error & & 2118.578 & 87 & 24.351 & & \\
\hline Total & & 289061.000 & 120 & & & \\
\hline Corrected Total & & 11716.325 & 119 & & & \\
\hline
\end{tabular}

a. $\quad \mathrm{R}$ Squared $=.782($ Adjusted $\mathrm{R}$ Squared $=.702) \quad * \mathrm{P}<0.0 .5$

From table 5, the F-value (4.594) is significant because the P-value of 0.000 is less than 0.05 level of significant i.e. $\mathrm{P}(0.000)<0.05$. This led to the rejection of the null hypothesis. This means that teachers' attribute has significant influence on students' academic performance in Mathematics. 
Hypothesis 2: School environment has no significant influence on students' performance in Mathematics

Table 6: Two-way Analysis of Variance (ANOVA) for influence of school environment on students' academic performance in Mathematics

\begin{tabular}{|c|c|c|c|c|c|c|}
\hline Source & & Sum of Squares & Df & Mean Square & $\mathbf{F}$ & Sig. \\
\hline Corrected Model & & $7590.822^{\mathrm{a}}$ & 19 & 399.517 & 18.796 & $.000^{*}$ \\
\hline Intercept & & 138634.799 & 1 & 138634.799 & 6522.446 & $.000^{*}$ \\
\hline School Environment & & 41.889 & 6 & 6.982 & .328 & .921 \\
\hline Performance & & 4552.433 & 2 & 2276.216 & 107.091 & $.000^{*}$ \\
\hline School Environment & * & 186.370 & 11 & 16.943 & .797 & .643 \\
\hline \multicolumn{7}{|l|}{ Performance } \\
\hline Error & & 2125.503 & 100 & 21.255 & & \\
\hline Total & & 287061.000 & 120 & & & \\
\hline Corrected Total & & 9716.325 & 119 & & & \\
\hline
\end{tabular}

R Squared $=.781$ (Adjusted R Squared $=.740$ ) $\quad{ }^{*} \mathrm{P}<0.05$

From Table 6, the F-value (0.797) is not significant because the P-value of 0.643 is greater than 0.05 level of significant i.e. P $(0.643)>0.05$. This led to the non-rejection of the null hypothesis. This means that school environment has no significant influence on students' performance in Mathematics. By implication, school environment has no influence on students' academic performance in Mathematics.

Hypothesis 3: Parental factor has no significant influence on students' performance in Mathematics

Table 7: Two-way Analysis of Variance (ANOVA) for influence of parental factor on students' performance in Mathematics

\begin{tabular}{llllll} 
Source & Sum of Squares & Df & Mean Square & F & Sig. \\
\hline Corrected Model & $7392.446^{a}$ & 25 & 295.698 & 11.961 & $.000^{*}$ \\
Intercept & 140520.280 & 1 & 140520.280 & 5683.990 & $.000^{*}$ \\
Parental Factor & 29.024 & 8 & 3.628 & .147 & .997 \\
Performance & 4115.135 & 2 & 2057.568 & 83.228 & $.000^{*}$ \\
Parental Factor * Performance & 2074.518 & 15 & 138.301 & 5.594 & $.000^{*}$ \\
Error & 2323.879 & 94 & 24.722 & & \\
Total & $\mathbf{2 8 9 0 6 1 . 0 0 0}$ & $\mathbf{1 2 0}$ & & & \\
Corrected Total & $\mathbf{1 1 7 1 6 . 3 2 5}$ & $\mathbf{1 1 9}$ & & & \\
\hline
\end{tabular}

R Squared $=.761$ (Adjusted R Squared $=.697$ ) $\quad{ }^{*} \mathrm{P}<0.05$

From Table 7, the F-value (5.594) is significant because the P-value of 0.000 is less than 0.05 level of significant i.e. $\mathrm{P}(0.000)<0.05$. This led to the rejection of the null hypothesis. This means that parental factor has significant influence on students' academic performance in Mathematics.

Hypothesis 4: Students' disposition has no significant influence on students' performance in Mathematics.

Table 8: Two-way Analysis of Variance (ANOVA) for influence of students' disposition on students' academic performance in Mathematics

\begin{tabular}{llllll}
\hline Source & Sum of Squares & Df & Mean Square & F & Sig. \\
Corrected Model & $7381.238^{\mathrm{a}}$ & 19 & 388.486 & 16.637 & $.000^{*}$ \\
Intercept & 131081.135 & 1 & 131081.135 & 5613.543 & $.000^{*}$ \\
Students' Disposition & 21.355 & 6 & 3.559 & .152 & .988 \\
Performance & 4364.919 & 2 & 2182.460 & 93.464 & $.000^{*}$ \\
Students' Disposition * Performance & 2087.269 & 11 & 189.752 & 8.126 & $.000^{*}$ \\
Error & 2335.087 & 100 & 23.351 & & \\
Total & $\mathbf{2 8 9 0 6 1 . 0 0 0}$ & $\mathbf{1 2 0}$ & & & \\
Corrected Total & $\mathbf{1 1 7 1 6 . 3 2 5}$ & $\mathbf{1 1 9}$ & & &
\end{tabular}

R Squared $=.760$ (Adjusted R Squared $=.714) \quad{ }^{*} \mathrm{P}<0.05$

From Table 8, the F-value (8.126) is significant because the P-value of 0.000 is less than 0.05 level of significant i.e. $\mathrm{P}(0.000)<0.05$. This led to the rejection of the null hypothesis. This means that students' disposition has significant influence on students' academic performance in Mathematics.

\section{Discussion and Conclusion}

This study revealed that the level of students' academic performance in Mathematics in senior secondary schools is low. This finding agreed with the conclusion of Oshokoya and Omoteso, (2018) that many students fail Mathematics each year and so end up forfeiting the pursuit of many careers that should have benefitted 
them and the country better. The finding of the study revealed that the teachers' attribute has significant influence on students' academic performance in Mathematics. This corroborated with the work of Okoruwa (2009) found that teachers' teaching experience has significant effect on students' achievement in the sciences. This finding also revealed that the school environment has no significant influence on students' academic performance. However, the school environmental factor is the least predictor of academic performance of students in Mathematics. The finding disagree with the opinion of Black, (2001) and Fettler (2009) found that students in old buildings scored 5-7\% points lower than students in new buildings and so established independent findings that there is a relationship between the school environmental condition and students' achievement. However, high performance school could be traced to improve acoustical environment. The finding of the study also shows that parental has significant influence on students' academic performance in Mathematics. This is in agreement with Mihaila, (2012) that greater parental involvement at early stage in children's learning, positively affects the child's school performance including higher academic achievement. The finding was in concordance with Oshokoya and Omosteso (2018) who stated that educational background of the parent is one of the important aspects in the study of Mathematics. This implies that socio-economic status of parents has a great impact on the students' performance in Mathematics. This finding also revealed that students' disposition has significant influence on students' academic performance in Mathematics. However, Students' disposition is the most predictor of academic performance in Mathematics. This agree with Olatunde (2010) who in a research conducted on students' self-concept and Mathematics achievement contented that, students who have positive self-concept of themselves performed well in Mathematics. The child who views himself and his abilities positively is the one who can maximally benefit and achieve good results in school learning experiences.

Based on the findings obtained in the study, the researchers make the following recommendations: Parents should be sensitized on the need to provide for the educational needs that will motivate the children to learn effectively and perform satisfactorily in schools; Family counseling services should be intensify in order to sensitize couples on the need to reduce the incidence of divorce and broken homes in the society so as to enable children benefit from intact family upbringing; Teachers should, as much as possible, try to reduce the anxiety level of students and promote student interest in Mathematics; The school counselors should monitor what goes on in the home with a view to providing students with learning experiences commensurate with their circumstances. It is believed that the suggestions presented in this study could be implemented with minimal financial input and would reverse the parlous state of student's under-achievement in Mathematics in Nigeria.

\section{REFERENCES}

Adewumi, M. G., Olojo, O. J and Falemu, F.A. (2012). Roles of parent on the academic performance of pupils in elementary schools. International Journal of Academic Research in Business and Social Sciences. 2 (1), 5661.

Bed, R. A.(2017) Factors affecting difficulties in learning mathematics by mathematics learners not. Journal of Elementary Education 6 (2), .8-15.

Bilesanmi, T. A (2009). A causal model of teacher characteristics and students achievement in some educational concepts. Unpublished PHD thesis, University of Ibadan, Ibadan.

Bitrus, G. A and Doniya, G. A. (2016). Parents' level of education as predictors of academic performance of nce students of colleges of education in the North-Eastern State of Nigeria. IOSR Journal of Humanities and Social Science (IOSR-JHSS). 21 (2), 41-47

Black, S. (2001). Building blocks: How schools are designed and constructed affects how students learn. American School Board Journal, 188 (10), 44-47.

Demirbağ,T .(2020). Views of students and teachers about role of homework implementation on students' academic success. The Universal Academic Research Journal,2(2),64-77.

Demirtaş,Z. \& Arslan,N. (2018). Teachers' Achievement Goals: A Mixed Method. Universal Journal of Educational Research, Universal Journal of Educational Research,4,710-720.

Ella, R.E., Odok, A.O. \& Ella, G.E.(2015) Influence of family size \& family type on Academic performance of students in Government in Calabar Municipality, Cross River state, Nigeria int. Journal of Humanities social sciences $\mathcal{E}$ educ., (1JHSSE) 2 (II), 2349-2373.

Eyong,E,I., Ugada,C. \& Aminu,A. (2020). Indicators of improved achievement of students' in mathematics. The Universal Academic Research Journal,2(1), 29-37. 
Fettler, E (2009). The relationship between measures of teacher experience with Mathematics educational level and students' achievement in Mathematics in the critical importance of well-prepared teachers.U. S Department of Education.

Francis, A. (2007). Student and teacher related variables as determinants of secondary school student academic achievements in Chemistry. JurnalPendidikan, 32, 3-18.

Green, A., Little, A., Kamat S., Oketch, M. and Vickers, E., (2007). Education and development in a global era: Strategies for successful globalization. London: DfID.

Hariyani,S. Ahmad,N.J.\&Marsitin,R. (2021). Mathematics teaching practicum for junior high school in a different culture-based situation. The Universal Academic Research Journal,3(2),77-86.

Hatiz, M.R., Tehsm, M.S., \& Muhammed A.K (2003). Parental involvement \& academic achievement. Int. Journal of Humanities E Social Sci. (Special issue).

Hill, H. C., Rowan, B., \& Ball, D. L. (2005). Effects of teachers' mathematical knowledge for teaching on student achievement. American Educational Research Journal,42(2), doi.org/10.3102/00028312042002371.

Ifiokobong, I (2016). Problem and prospect of mathematics education in Nigeria. Information Guide in Nigeria.

Isangedigh, A. J (2008). Under-achievement: An index of learner-environment mismatch Nigerian Journal of Educational Psychology, 3(1),220-226.

Isola, O. M. (2010). Effects of standardized and improved instructional materials in students' academic achievements in secondary school. M.Ed Thesis, University of Ibadan, Ibadan.

Karagöz,S. (2021). Evaluation of distance education: The sample of guidance and counseling students. The Universal Academic Research Journal,3(1),18-25.

Kolawole, E.B. \& Oginni, O. I. (2009). Effectiveness of laboratory methods of teaching on students' performance in senior secondary school Mathematics (Abacus). The Journa lof Mathematical Association of Nigeria, 34, (1), 120-125.

Kurumeh, M. S. C (2004). Effects of ethno mathematics teaching approach on students' achievement and interest in geometry and mensuration. Unpublished PHD Thesis, University of Nigeria, Nsukka. Lagos Journal of Science Education (1), 7-13.

Limb, S. \& Fullarton, S. (2001). Classroom and school factors affecting mathematics achievement: A comparative study of the US and Australia using TIMSS. Australian Council for Educational Research (ACEReSearch).

Maduabum, M. A (2009). Science teacher effectiveness and national goal attainment in Nigeria: $11^{\text {th }}$ Inaugural lecture. Abia State University, Uturu.

Maganga, C. K. (2013). Evolution of philosophical discourses on education: A clarification. Tanzania Open School and Publishing House: Dar es Salaam.

Mihaila, T (2012).The influence of socio-Economic status on school performance Romaman Journal of Experimental Applied Psychology, 3 (2).

Mtitu, E. A (2014). Learner-centered teaching in Tanzania: Geography teachers' perceptions and experiences. Victoria University of Wellington.

Oyetakin, S.O (2014). Household structure and students' academic performance. A comparative analysis of children raised by grandparents \& single parentage. European Scientific Journal Nov. 2014/SPEGALl/edition . 2 ISSN: 1857-7881 (Print) - ISSN 1857-7431.

Quimbo, S. L (2010). Explaining Math and Science Achievement of Public School Children in the Philippines. Philippine Review of Economics: Philippines.

Robertson, S. Novelli, M. Dale, R. Tikly, L. Dachi, H. \& Ndebela, A. (2007). Globalization, Education and Development: Ideas, Actors and Dynamics. London: DFID.

Sidhu, K. S (2005).The Teaching of Mathematics New Delhi: Sterling Publishers private Limited.

Uche S.A and Chinyere F.O (2013). Poor Performance of Nigerian Students in Mathematics in Senior Secondary Certificate examination (SSCE): what is not working? JORIND 11(2) December, 2013. ISSN $1596-8303$. 